\title{
Development of Testamentary Inheritance Institution in Albania
}

\author{
Nertila Sulçe \\ Attorney at Law, National Registration Center, Tirana, Albania
}

\section{Doi:10.5901/mjss.2015.v6n3p36}

\begin{abstract}
Inheritance is an ancient institution recognized by the Roman law in the Twelve Tables (303 BC) in which the testamentary right was given priority. The testament, in its written form, was initially observed in wax tables, then called "praetorian testament", which as a historical period corresponds to the Classic one (late period of ancient Rome). The testament is a legal action made by the testator through which he disposes his property after death. The testament is an action upon death, personal, that can only be done by the testator and not another person. Generally there are two forms of testaments, ordinary and special testaments. During the years 1912-1929, testamentary inheritance was regulated according to the religion the testator belonged to. The Civil Code of 1929 defines testament as a revocable act through which the testator disposes all or part of his property, referring to the time after his death, in favor of one or more persons. During the communist dictatorship, testamentary heirs could be legal heirs, state authorities and social organizations, but in any case it was not allowed to dispose property via testament in favor of the church or religious institutions. Pursuant to the Civil Code in force, the testament is a legal action arising out of death or mortis causa. In such cases when the testator disposes only a part of his property, for the property which is not disposed by testament, legal inheritance shall apply. This paper analyzes the testament institution in Albania during various periods up to the Civil Code in force, that of 1994.
\end{abstract}

Keywords: Inheritance, testament, mortis causa action, etc.

\section{Introduction}

Inheritance is an ancient institution recognized by the Roman law in the Twelve Tables ( $303 \mathrm{BC}$ ) in which the testamentary right was given priority. The testament, in its written form, was initially observed in wax tables, then called "praetorian testament", which as a historical period corresponds to the Classic one (late period of ancient Rome). This form of testament was highly improved with the passing of time and became the basic template not only for many of the countries applying Continental Law, but also in other countries as well. The person stating the transfer of his property by presenting the tables and confirming that the writing contained herein expressed his last will, also required the approval from the people who were present to appear as witnesses thereof in case it was necessary, by addressing them a call. This call gave the name to the entire action which was then called testamentum ${ }^{1}$. Inheritance relations themselves were born when ownership was born, and shall exist as long as the right of ownership will cease to exist. Such relations are developed following the steps of society development and originate back to the primitive society. However, we cannot say that during that time there was an Inheritance Law per se. The inheritance institution may be considered as the point from which diverse and complicated problems arise in the private international law, not only with regards to the opinion of different doctrines, but especially due to the divergences between different legislations and due to practical difficulties resulting as a consequence thereof. ${ }^{2}$ The Testament is a one-sided statement of the testator's will, given in a form as prescribed by the law, which aims to create a new order of inheritance and not that envisaged by the law. This is a mortis causa action and through it, a part or the entire property may be disposed, or one or more legal heirs may be expelled from inheritance or they may be charged with different obligations. The Testament is a highly personal action and this paper shall address this institution by analyzing its development in different periods in Albania.

\section{Post Independence Inheritance Institution and Pursuant to the Civil Code of 1929}

During 1912-1929, Albania applied the norms of the Turkish Empire to regulate inheritance relations. Such norms were based on Sheriat, the sacred law deriving from Kuran. Testamentary inheritance was regulated according to the religious

\footnotetext{
1 Juliana Latifi "Trashëgimia me testament, vështrim krahasues ", Shtëpia botuese Lilo 1999, fq.16

${ }^{2}$ Agim Tartari "Trashëgimia në të drejtën ndërkombëtare private", botim i Kumit, 2010 fq.11
} 
norms that the testator belonged to.

By way of testament one could dispose a part of the property or only special types of property, such as mylk and not completely, but only $1 / 3$ of it. In case the testator would dispose through testament a larger share of mylk property, then the testament validity for such part which exceeded $1 / 3$ depended on the satisfaction of the legal heirs. Another restriction for the testator with regards to his testament was the fact that if he disposed his estate through testament only to the benefit of one of the heirs, the testament would be applied only in case the other heirs approved it ${ }^{4}$. In 1922 Albania approved the Decree-law on testaments (dated 05.04.1922) which regulated property inheritance through testament. Based on this law, one could also dispose through testament $1 / 3$ of the property and in cases when there were no legal heirs, one could leave $2 / 3$ of its property, whereas $1 / 3$ passed to the state. The Civil Code of 1929 defines the testament as a revocable act with which the testator disposes all or part of his property, after death, in favor of one or some persons ${ }^{5}$. The capacity to make a testament was vested only to those who reached the age of 18 years old and were not divested of their capacity to act. People who could not make a testament, even though not being divested from the capacity to act, due to their health condition or mental development were not able to understand the importance of the action they were going to make and the consequences resulting thereof. Such Code envisaged two types of testaments, the ordinary and the special one. The provisions of the Civil Code of 1929 envisaged two forms of ordinary testament, the holographic testament and the notary act ${ }^{6}$. The holographic testament, to be valid, should be entirely handwritten and signed by the testator, as well as bear the date, month and year of its writing; whereas the notary act testament could be public or secret. The public notary testament was drafted by the notary in the presence of four witnesses, or in the presence of two notaries and two witnesses and should be signed by the testator, the notary or notaries as well as the present witnesses. The secret notary testament could be written by the testator himself or by another person and should be signed at any time by the testator and submitted safely covered in the presence of four witnesses ${ }^{7}$. Special testaments were further divided into: a) testaments made under exceptional circumstances; b) testaments made during sea voyages, when the ship was in the sea or in foreign ports and it was not possible to communicate with the Albanian land. a) Testaments made under exceptional circumstances could be made by the person through a written letter taken from the notary or justice of peace, or neighborhood or village priest in the presence of two witnesses.

In this case the testament should be signed by the person who received it, and when allowed by the circumstances, by the testator and the witnesses. The testament prepared in this form had no force when a month passed from the time the testator regained the freedom to make a testament in the ordinary form and did not do it ${ }^{8}$. b) Testaments made during sea voyages, when the ship was at sea or in foreign ports and it was not possible to communicate with Albanian land; In cases when the ship was in open sea or in foreign seaports, where there were no diplomatic agents or Albanian consuls, the testament written by the testator was taken in the presence of two witnesses in the ships of Albanian state by the administrative officer or ship commander or their vices. In private ships it was taken from the captain or owner of the ship, or from their representatives. The Testament was prepared in two original copies and it had to be signed by the persons receiving it as well as by witnesses. Such testament was valid when the testator died in the sea or within a month from the day he had landed and did not have any possibility to make an ordinary testament. According to the Civil Code of 1929 the legal reserve referred to legitimate descendants, ascendants, siblings of the testator who benefited their part, and the testator could neither dispose them through testament nor charge them any condition or encumbrance 9 . In contrast with this code, the Civil Code in force provides the legal reserve only for minor children of the testator or other minor heirs, who inherit by representation, as well as other persons disable to work in case they are called in inheritance.

\footnotetext{
${ }^{3}$ Mylk property as per the Ottoman Law is the property under full private ownership of the owner, free of any dependence from the state and church, be that real or not.

${ }^{4}$ Ardian Nuni,Luan Hasneziri E drejta civile III (Trashëgimia), Tiranë 2010, fq. 270

${ }^{5}$ Article 429 of the Civil Code of 1929 provides: "The testament is a revocable act with which anyone, as per the rules prescribed by law, dispose for the time after his death, all or part of his property in favor of one, or more persons".

${ }^{6}$ Article 507 provides: "The Law recognizes two forms of ordinary testaments: the holographic testament and the notary act testament", (emphasis added).

${ }^{7}$ Article 515, 516 of the Civil Code of 1929.

${ }^{8}$ Article 523 of the Civil Code of 1929.

${ }^{9}$ Article 536 of the Civil Code of 1929.
} 


\section{Inheritance Institution during Communism (1944-1954, Decree No 1892, dated 05.07.1954 "On Inheritance" and Civil Code of 1982)}

Testamentary heirs could be legal heirs, state organs, as well as social organizations. When there were no legal heirs, it was allowed for the property to be disposed through testament in favor of other persons, but not to the church. ${ }^{10}$ Property could not be diposed in favor of religious institutions in cases when there were no legal heirs, due to the hostile attitude shown towards such institutions and religion in general. Decree No 1892, dated 05.07.1954 "On Inheritance" defines testament as a one-sided juridical action conducted by the testator himself through which he deposes his wealth after death ${ }^{11}$. The capacity to make a testament arised to everybody who reached the age of 18 years old and as a person under this age when he/she was married. For 14-18 year old minors, the testament could only be made for the property they had gained through their work.

It was not allowed to dispose property through testament to persons whose capacity to act was revoked upon a final court decision, as well as to the persons who while doing the testament were not able to understand the importance of their action. The Decree on inheritance under article 41 provided that the notary act was a valid form for the testament. The testament was made through an edited act or certified by the notary and signed by the testator. The testament should have the form of notary act; otherwise it would be invalid. ${ }^{12}$ Expectance from this Decree were the testaments edited in regions where there were no notary offices or which were made by one person serving the military service or in an Albanian ship which was sailing or situated in a foreign harbour. In such cases the testament was certified by the chair or secretary of the country or city people's council, by the commander of the military unit in which the testator was part, when hospitalized for treatment by the hospital director, and when aboard a ship by the ship's captain ${ }^{13}$. In contrast with the Civil Code of 1929, this decree did not recognize the testament written by the testator himself, thus the holographic testament. With the changes made in 1960 regarding the testament form, it was accepted that the testament could also be written by the testator himself (holographic testament), article 41. The testator could not dispose the entire or part of his wealth to any person. First of all he is obliged to dispose such property through testament only to those persons indicated by articles 21, 22 and 23 of the Decree on Inheritance. Only when there is none of the heirs mentioned in such articles (i.e., children, offsprings of children, spouse, parents, siblings, and persons with disabilities to work under the charge of the testator) he could dispose his property to any other person, as per article 32 of the Decree. ${ }^{14}$ Property could pass to a social or state organization. Furthermore, such decree did not allow disposing property in favor of religious institutions. The Legislative has forbidden to dispose through testament the belonging part of minor children or minor children of their children, as well as the part of other heirs with disabilities to work in case that according to legal inheritance they have the right to be called in an inheritance. Counter dispositions are invalid and in case with this disposition inheritance is changed its form of ownership, i. e., it is allowed to pass in favor of the state ${ }^{15}$. A particularity of the Decree on Inheritance is that it also envisaged inheritance in agricultural economy, where inheritance over the joint estate of the agricultural family started only when the last member of the agricultural family died, and disposition through testament of land was forbidden (article 58). The agricultural family was composed by all the persons, without discrimination of sex, age, related among them due to gender, marriage, adoption or persons who do not have any gender relation, but who are accepted as members in the agricultural family and who together with their work or with their means earn the living of such family ${ }^{16}$.

The Civil Code of 1981 regulated the inheritance institution with only 25 provisions in contrast with the Civil Code of 1929 which regulated it with 319 provisions, and more concretely in heritage through testament was regulated by articles 110-118. In contrast with the Decree on Inheritance, such Code did not recognize the capacity to dispose through testament the wealth gained with their work to minor children from 14-18 years old. Referring to article 112 of this Code, the testator could leave through testament his entire property or a part of it to a heir or more heirs envisaged by articles 104, 105 and 106 (i.e., children, offspring's of children, able and disable spouse, able and disable parents, grandfather and grandmother, sisters and brothers, children of brothers and sisters that had died, persons with disabilities to work under the charge of the testator), state or enterprises, institutions, agricultural cooperatives or social organizations. The

\footnotetext{
10 Nazmi Biçoku "E drejta e trashëgimisë së Republikës së Shqipërisë" shtëpia botuese "albPaper", Tiranë 2011, fq.37.

${ }_{11}$ Article 30 of Decree No 1892, dated 05.07.1954.

${ }^{12}$ Andrea Nathanaili, Nonda Papuli "Disa çështje mbi pronësinë dhe trashëgiminë”, Botim i Ministrisë së Drejtësisë, Tiranë 1961, fq.100.

${ }^{13}$ Articles 41,42 and 43 of Decree No 1892, dated 05.07.1954.

14 Hilmi Dakli "Trashëgimia me testament”, Drejtësia Popullore, Janar 1955, fq.44

${ }^{15}$ Kleanthi Koçi "Disa çështje kryesore lidhur me institutin e trashëgimisë në shoqërinë tonë" Drejtësia Popullore, Korrik-Gusht 1972, fq.13

${ }^{16}$ Article 90 of Decree No 1892, dated 05.07.1954.
} 
testamentary testator could expel from inheritance one or more of his legal heirs, but he could not touch the part belonging to minor children or other minor heirs who inhereited via representation, as well as to other disable heirs. Such code also expelled the possibility of disposing property to religious institutions or to the church. With regards to the testament, it was made through a notary act or written by the testator himself ${ }^{17}$. The testament through notary act was made with an edited act or certified by the notary and signed by the testator. The testament written by the testator was written entirely by the testator himself, bears the date when written and signed in the bottom by him. According to this

Code, the testament was invalid in one of the following cases:

a) when is made by a person who did not have capacity to act;

b) when it was not made in the form required by law;

c) when it was made in favor of persons who could not inherit;

d) when it was made by violating the legal reserve for minor children, of other minor descedants without limitation or disabled persons under the charge of the testator ${ }^{18}$.

\section{The Testament Institution Pursuant to the Civil Code of 1994}

According to the Civil Code in force the testament is a one-sided juridical action conducted by the testator himself through which he disposes his property after death ${ }^{19}$. The testament is a juridical action arising due to death or mortis causa. It is a highly personal action, which may be conducted by the testator himself and not anyone else.

It is an action which can be revoked at any time and the testator is not obliged to indicate the reasons of such revocation and with a solemn formal juridical action which should be in the form required by the law, otherwise it is invalid. The testator disposes inheritable property to the testamentary heir through a testament. In such cases when the testator disposes only a part of his property, for the property which is not disposed by testament, legal inheritance shall apply. Inheritable property is composed by movable, immovable property, as well as rights related to such property. Based on article 332 of the Civil Code, the testator may win all the property of the testator or a part of it, only a certain item or a part of it, or a certain item or property right. Referring to the unifying decision of the High Court No 1, dated 24.03.2005: (...) In the case of testamentary inheritance, given the fact that the source of call in inheritance is the will of the testator himself, the extension to inheritance rights is exclusively related to determined relations by the testator, who formulates his will through an one-sided juridical action, the testament. As a result, the call for inheritance in the case of testamentary inheritance could be not only over the entire inheritable property or a part of it - with universal title, but also on one or special items - with special title. Only universal heirs or those who have the universal title have the judicial capacity to benefit even property elements, which de cuius are not envisaged expressly in the testatement. The special title heir has a limited right related to the items or the rights determined expressly in the testament, and as a result, the changes of inheritable property found at the moment of starting the inheritance process, shall not be reflected in their title 20 ". As an one-sided judicial action, the testament brings consequences only with the willful declaration of the testator and the persons called heir in it are not required to give their consent at the onset of this action in order to be called as heirs ${ }^{21}$. The testator is not completely free to dispose his wealth in favor of a person, but he is obliged to respect the legal reserve of minor children and/or other minor descendants without limitation, of disabled persons in case they are called in inheritance, as well as dispose his property within the three first rows of legal heirs when there are such. According to the Italian law on legal children, legitimated or adopted, there exists a legal reserve according to which they benefit wealth equal to the half of inheritable property, in case there is only one child or equal to $2 / 3$ in case there are two children or more. (Article 537 of the Italian Civil Code). Pursuant to the Common Law system, the spouse cherishes the right of selection, according to which he has the right either to accept the conditions of the testament or choose against it, thus, taking the part that would belong to him legally in full ownership22.

The capacity to make a testament is the capacity of the physical person who willfully and in accordance with the law may dispose his entire or partial property, after death, in favor of one or some other persons. Such capacity is found in any person who has reached the age of 18 years old, as well as women under this age when they are married. A minor child ranging from 14-18 years old may make a testament only for the property he has gained through his work. ${ }^{23}$ The

${ }_{17}$ Article 115 of the Civil Code of 1981.

${ }^{18}$ Article 118 of the Civil Code of 1981.

${ }^{19}$ Article 372 of the Civil Code.

20 High Court Decision, No 1, dated 24.03.2005, date of approval 24.03.2005, Official Journal No 74,2005.

21 Valentina Kondili "E drejta civile II Pjesa e posaçme, Pronësia, të drejtat reale të përkohshme dhe trashëgimia" Geer 2008, fq.222.

${ }^{22}$ Rezana Konomi dhe Merita Prifti "Trashëgimia testamentare", Jeta juridike Numri 4 Viti XII, Tiranë Dhjetor 2012, fq.85.

${ }^{23}$ Article 373 of the Civil Code. 
married woman under 18 years old does not lose such capacity even when the marriage is declared invalid or dissolved. However, there is a loophole in this law because it does not include the capacity of persons under 18 years old. Therefore, full capacity to make a testament should not only have divorced spouses or spouses dissolved by stating their marriage as invalid, but also those under 18 years old who have remained widowed due to the death of their spouse ${ }^{24}$. Persons whose capacity to act is removed by court decision as well as persons who at the time of making a testament are not able to understand the importance of their action thereof, may not make a valid testament. In addition, persons under 14 years old do not have capacity to dispose at all, since they have no capacity to act in general. In contrast with the Albanian legislation, the Italian Civil Code (articles 591, 592), as well as the French Civil Code (articles 901 and further and 1035 and further), both consider as unable to make a testament even persons sentenced with life imprisonment or for a long period of time. With regards to the capacity to win through testament, this capacity is owned by such persons who can inherit by law and who are alive at the moment the inheritance process is opened or who are conceived prior to the death of the testator and were born alive. Unable to win through testament are those persons who are unable to inherit by law, apart from direct children of a certain person and alive at the time of death of the testator, even though such children were not conceived yet ${ }^{25}$.

The following do not have capacity to inherit: any heir who has died prior to the testator, any heir was has become indecent to inherit and has been expelled from inheritance or has waived. Children who enter by representation in this case should be alive at the time the testator dies or be conceived prior to his death and born alive. The Civil Code forbids the custodian to benefit property through testament by disposition of the person under his custody prior to the final approval of accounts even though the testator had died after the final approval of accounts ${ }^{26}$. The Civil Code envisaged two types of testaments, the ordinary testaments and testaments made under special circumstances. The ordinary testaments are the holographic testament and the notary act testament. The holographic testament, to be valid, should bear a clear and readable handwriting of the testator, bear the date when it was written, indicating the day, month, and year. ${ }^{27}$

Referring to article 602 of the Italian Civil Code, the conflict on the authenticity of the holographic testament date is allowed only when the capacity to make a testament is being judged or in the case when a priority of giving a date is confirmed among many testaments or to determine it by taking into consideration the time it was written. According to the French legislation and jurisprudence in general, the lack of a date may be regulated in accordance with the evidence of the testament itself or through external proof. However, according to the Albanian legislation, an holographic testament without a date, even though the date can be inferred by its content, makes it invalid, since it lacks one of the indispensible elements of form. The holographic testament shall be considered invalid if the testament is written in a typewriter, computer or other devices. The holographic testament is allowed only to those persons who are literate, who can read and write, otherwise they cannot make a holographic testament. According to the law "On Notary", the holographic testament may be deposited at the notary to be kept in a sealed envelope at the notary office. In this case, the notary is obliged to keep a written record, which bears the date of acceptance, the full identity of the person, and the description of the deposited document ${ }^{28}$. With regards to the notary act testament it is prepared by the notary after the testator has expressed to the latter his will and is signed by the testator in the presence of the notary. The notary act testament presents more security both for the content and for the will expressed by the testator himself. While the notary is preparing the testament, the notary is obliged to verify the identity of the disposing person, whether such person has juridical capacity to act, whether he is able to understand the importance of his action or whether he is making this testament without his free will. Otherwise, the notary should refuse the preparation of such testament. The notary is obliged to know the testator with regards to all law requirements and limitations and only after this he can start to prepare the testament ${ }^{29}$. The notary should respect the expression of the testator's free will and never intervene in the testator's will. While preparing the testament, the notary, based on article 52 of the law mentioned above, may not refuse to prepare the testament claiming that the testator is not the owner of the property he is diposing through testament, or that the testament violates the legal reserve or that the disposition through testament is made beyond the row of legal heirs. However, the notary is obliged to refuse the preparation of the testament when its content is in contradiction with public order. In such cases, the notary, within five days notifies the concerned person about the refusal for the preparation of

\footnotetext{
${ }^{24}$ Arben Hakani "Trashëgimia testamentare" Legjislacioni dhe praktika gjyqësore, Botimet Dudaj 2010, fq.62.

${ }^{25}$ Indirect child means a person who does not come directly from the testator, bur is the nephew or great nephew with whom he is indirectly related.

${ }^{26}$ Article 375 of the Civil Code.

${ }^{27}$ Article 393/2 of the Civil Code.

28 Juliana Latifi "E drejta civile, Trashëgimia" Geer 2007, fq.85.

${ }^{29}$ Article 40 of the law "Për Noterinë".
} 
such testament, and the testator has the right to address a complaint at the district court in whose territory the notary office is situated. The notary should be careful in particular when making testaments of old and diseased people. In such cases the notary should be sure about their mental state, as well as for the expression of their free will. The notary where such act is deposited starts the notary statement after receiving a request from the persons concerned. The notary should keep a written record where to write the act of death and make the transfer of testament to the general register of notary acts.

In case there is no request from the persons concerned to open the testament deposited at the notary office, the notary is obliged to inform them. The Civil Code envisages special testaments also. Such a testament is the one prepared by the testator himself in a country belonging to the administrative unit which does not have a notary. In such a case, the testament is certified by the mayor or head of commune ${ }^{30}$. This kind of testament in practice is seldom found due to the fact that the testator either chooses the notary form, or the holographic testament form, and in the case when in his commune or municipality there is no notary, the testator goes to the closest commune or municipality that has a notary to prepare the testament. ${ }^{31}$ Another kind of testament is the one that the person does when he is under military service or hospitalized. In the case of the person who disposes his property via testament under military service, this act may be certified by the commander of the military unit where is part of. ${ }^{32}$ This kind of testament can be prepared by military men, both permanent officials and temporary ones who serve their mandatory military service. This kind of testament could be made in special circumstances that hinder the person to make a testament in the ordinary forms envisaged by the law. Another case is that of the person who makes a testament when hospitalized for treatment. In this case the testament made by him could be certified by the hospital director ${ }^{33}$. A person may make such a testament when found under serious health conditions, so serious that his life might be at risk and it is impossible for him to go to the notary.

Another type of testament is when the person who disposes his property via testament is in an Albanian ship which is sailing or has stopped in a foreign port. In this case the testament may be certified by the ship captain ${ }^{34}$. In this case the person does not have any possibility because of any disease or any other circumstances to wait for the ship to come back and make a testament at the notary. A weakness of the Civil Code in force is that in contrast with article 42 as amended of the Decree "On Inheritance" and the Civil Code of 1929 (article 523 up to 531), which envisaged detailed rules in relation to the validity term of such testaments and the method of their replacement with ordinary testaments, the Civil Code in force does not envisage any validity term and does not envisage the method of their replacement with ordinary testaments. This way, being that there is no term, we can say that such special testaments are valid as any other testament. Analyzing the content of the Civil Code of 1929, it is important to mention that there are many similarities with the Italian Civil Code for many institutions, including testament forms. The Italian legislation classifies testaments as ordinary (article 601) and special (article 609). With regards to the ordinary form, it is envisaged the holographic and the notary act testament. The notary act testament may be a public or secret act.

The French Civil Code, in contrast with the Albanian legislation and the Italian one, in article 969 envisages three usual forms of the testament: the holographic testament, the public act and the secret act. Such legislation also envisages the international testament if it does not contradict the forms of French law. Article 976-980 of the French Civil Code envisages the mystic testament which is closed and sealed at the notary, in the presence of two witnesses. After its deposition at the notary, the latter prepares a signature act for the present persons - testator and witnesses, which bears the date of such testament. The mystic testament has advantages in contrast with the holographic testament, because it makes possible its secret maintenance. The various international legislations also recognize joint testaments in which are included reciprocal testaments when through the same act, two persons dispose in favor of each other, as well as collective testaments when some testators through the same act dispose in favor of a beneficiary ${ }^{35}$. Such testaments are forbidden by the French legislation (article 963 of the Civil Code) and by the Italian one (Article 589), whereas according to the Albanian legislation, the testament cannot be made by two or more persons in the same act, neither in favor of a third party nor with reciprocal dispositions ${ }^{36}$. Thus, based on such provision, joint and reciprocal testaments are invalid.

\footnotetext{
${ }^{30}$ Article 398 of the Civil Code.

${ }^{31}$ Ardian Nuni,Luan Hasneziri E drejta civile III (Trashëgimia), Tiranë 2010, fq.122.

32 See the first par. of article 399 of the Civil Code.

${ }^{33}$ See the last paragraph of article 399 of the Civil Code.

${ }^{34}$ Article 400 of the Civil Code.

${ }^{35}$ Agim Tartari "Trashëgimia në të drejtën ndërkombëtare private shqiptare" Botim 2010, fq.160.

${ }^{36}$ Article 372 of the Civil Code.
} 


\section{Issues Arising from Testament Application and Suggestions Improving Relevant Provisions}

Article 373 of the Civil Code envisages the capacity to dispose via testament that belongs to any person who has reached the age of 18 years old, as well as women under this age when married. The married woman under 18 years old does not lose such capacity even when the marriage may be declared invalid or dissolved. We suggest an improvement of such provision by including in it the capacity of widowed persons under 18 years old. Therefore, full capacity to make a testament should have not only spouses who are divorced or separated through declaration of their marriage as invalid, but also those less than 18 years old who have remained widows due to the death of their spouse.

Based on practice it results that in all cases, it is the testament preparation time which is verified and not the moment it is opened. In the case of testament preparation, for the testator it results that there are no heirs from those the law envisages, namely article 379 and 361/2 of the Civil Code. Later it results that after opening the testament there are some such heirs. It may happen even the contrary that during the preparation time there are heirs and during the opening moment there are not anymore. In this case we can say that many persons are obliged to alienate their property while alive by violating therefore their will and making the testament a formal and inapplicable juridical action.

Articles 398-400 of the Civil Code in force envisage special testaments which may be applied in exceptional or unforeseen circumstances, in which the concrete person may find himself. A weakness of the Civil Code in force is that it does not envisage any term for the validity of such testaments and nor the method of their replacement with ordinary testaments. For this reason, we suggest to include in such provision a certain term related to the validity of such special testaments.

The Civil Code envisages two forms of testaments: ordinary and special testaments. Due to the development of relations between different countries and continuous efforts for collaboration and creation of a common legislation it is preferable to include in the Civil Code in force, more various forms of testaments which are envisaged by the legislations of other countries, such as the international testament, etc.

\section{Conclusions}

The Testament is a juridical action which is born due to death or mortis causa, a highly personal action and which is revocable at any time. During the years 1912-1929 testamentary inheritance was regulated by religion norms to which the testator belonged. The Civil Code of 1929 defines testament as a revocable act through which the testator disposes entire or part of his property, referring to the time after his death, in favor of one or some persons. During the communist dictature testamentary heirs could be legal heirs, state organs and social organizations, but in no case it was allowed to dispose via testament property to the church or other religious institutions. According to Decree No 1892, dated 05.07.1954 "On Inheritance" the testament is defined as an one-sided juridical action, conducted by the testator himself, through which he disposed his property after death. Any person who had reached the age of 18 and any person under this age when married had the capacity to make a testament. A peculiarity of the Decree on Inheritance was that it envisaged inheritance in the agricultural economy, where inheritance over the common wealth of the agricultural family was started only when the last member of the agricultural family died and land was forbidden to be left via testament. A characteristic of the Civil Code of 1981 is the existence of a limited number of provisions which regulated inheritance and the failure to regulate a series of important institutions which regulated inheritance. The Civil Code of 1981 defines testament as an onside juridical action conducted by the testator himself through which he disposed his property after death by determining that the testator in any case would not violate the legal reserve of his heirs. The Civil Code in force envisages two kinds to testaments, the ordinary and the special one.

Testament cannot be made by two or more persons in the same act, neither in favor of a third party nor through reciprocal dispositions.

\section{References}

Agim Tartari "Trashëgimia në të drejtën ndërkombëtare private", botim i Kumit, 2010

Andrea Nathanaili, Nonda Papuli "Disa çështje mbi pronësinë dhe trashëgiminë”, Botim i Ministrisë së Drejësisë, Tiranë 1961

Arben Hakani "Trashëgimia testamentare" Legjislacioni dhe praktika gjyqësore, Botimet Dudaj 2010

Ardian Nuni,Luan Hasneziri E drejta civile III (Trashëgimia), Tiranë 2010

Dekreti Nr.1892, datë 05.07.1954 "Mbi trashëgiminë"

Francesco Galgano, "E drejta private",Tiranë 2006

Hilmi Dakli "Trashëgimia me testament", Drejtësia Popullore, Janar 1955

Juliana Latifi "E drejta civile, Trashëgimia" Geer 2007 
Juliana Latifi "Trashëgimia me testament, vështrim krahasues ", Shtëpia botuese Lilo 1999

Kleanthi Koçi "Disa çështje kryesore lidhur me institutin e trashëgimisë në shoqërinë tonë” Drejtësia Popullore, Korrik-Gusht 1972

Kodi Civil Francez

Kodi Civil i Republikës së Shqipërisë

Kodi Civil i vitit 1929

Kodi Civil i vitit 1981

Kodi Civil Italian

Ligji Nr.7829, datë 01.06.1994 "Për Noterinë"

Nazmi Biçoku "E drejta e trashëgimisë së Republikës së Shqipërisë" shtëpia botuese "albPaper", Tiranë 2011

Rezana Konomi dhe Merita Prifti "Trashëgimia testamentare", Jeta juridike Numri 4 Viti XII, Tiranë Dhjetor 2012, fq.85

Valentina Kondili "E drejta civile II Pjesa e posaçme, Pronësia, të drejtat reale të përkohshme dhe trashëgimia" Geer 2008

Vendim i Gjykatës së Lartë, Nr.1, data e aktit 24.03.2005, data e miratimit 24.03.2005, Fletore Zyrtare Nr.74, 2005 